\title{
Production of Some Chemically Modified Adsorbents from Some Field Crops by- Products to Reduce Ochratoxin A
}

\author{
May Mustafa Amer', Amal Mahmoud Abdel-Haleem², Tarek Ahmed El-Desouky 1,* \\ ${ }^{1}$ Food Toxicology and Contamination Department, National Research Centre, Al-Giza, Egypt \\ ${ }^{2}$ Crops Technology Research Department, Food Technology Research Institute, Agricultural Research Center, Al-Giza, Egypt
}

Email address:

eldesoukyt@yahoo.com (T. A. El-Desouky)

${ }^{*}$ Corresponding author

\section{To cite this article:}

May Mustafa Amer, Amal Mahmoud Abdel-Haleem, Tarek Ahmed El-Desouky. Production of Some Chemically Modified Adsorbents from Some Field Crops by- Products to Reduce Ochratoxin A. International Journal of Food Science and Biotechnology.

Vol. 3, No. 2, 2018, pp. 46-53. doi: 10.11648/j.ijfsb.20180302.12

Received: October 16, 2017; Accepted: October 27, 2017; Published: May 19, 2018

\begin{abstract}
This study aimed to produce some chemically modified adsorbents (CMA) from some field crops by- products to reduce ochratoxin A (OTA). Chemical modification was performed on broken rice starch, soybean hulls, and wheat bran to produce acetylated rice starch (ARS 8, ARS 16\%), modified soybean hulls (MSH), and micronized wheat bran (MWB). The presence of the new functional groups due to chemical modification was checked via Fourier Transform Infrared Spectroscopy (FTIR) method. The incidence of OTA in four types of commercial apple juice samples was studied. The efficacy of the chemically modified adsorbents (CMA) for reducing OTA at 500 and $1000 \mathrm{mg}$ was tested via HPLC method and applied at contaminated apple juice samples. From FTIR different stretching bonds and new functional groups at different band positions relates to chemical modification were detected. MSH, MWB, ARS $8 \%$ and ARS $16 \%$ at 500 and $1000 \mathrm{mg}$ were reduced OTA spiked solution by $(73.2,82.7) ;(79.5,84.03) ;(66.5,72.0)$, and $(70.9,75.8) \%$, respectively. The total number of contaminated apple juice samples with OTA was 33 out of 150 , and 13 of them exceeded the permissible limits of the EU. The reduction of OTA in all contaminated apple juice samples using CMA was 100\%, and the treated samples were highly acceptable by the panelists, and there were no significant changes in appearance, color, and flavor. The results of this study could be useful in utilizing broken rice, soybean hulls, and wheat bran; improving their adsorption capacities via chemical modification with acids and delivering highly reactive adsorbents to the food processors to produce safe food and remove OTA from contaminated apple juice.
\end{abstract}

Keywords: Field Crops by-Products, Chemical Modifications, Adsorption, Ochratoxin A and Apple Juice

\section{Introduction}

Nowadays, the motivation for the utilizing of the agricultural by-products is of great interest worldwide, due to their value added potentialities and high environmental impact [1-2]. Broken rice starch, soybean hulls, and wheat bran have been studied as potential precursors for the adsorption process [3-5]. Adsorbents derived from these byproducts are offering guaranteed advantages, as they are lowcost, renewable and available in large amounts [6], besides their chemical stability and high reactivity [7]. These materials can be used, either directly or after chemical modification, in the adsorption process [3]. Chemical modification with acids such as acetylation, dehydration, and micronization is considered to be an excellent method to improve the adsorption capacities of these sorbent materials. It provides more active sites, better ion- exchange, and significant adsorbate-adsorbent interaction [6-8] Ochratoxin A (OTA) is one of 400 types of identified mycotoxins produced by several species of Aspergillus and Penicillium fungi. The toxin has been classified as a possible human carcinogen especially, group 2B [9-10]. Ochratoxin is characterized by widespread occurrence in food and feed. It is found in cereals, pulses, dried fruits, cocoa beans, coffee beans, olives, and spices. Besides it can survive most food processing steps; therefore it appears in cereal- derived products, wine, beer, meat and cheese products, and juices [11-12]. In consequences, large efforts and several strategies 
were undertaken to decrease the incidence of OTA in agricultural commodities and food products. That may result in decrease the tolerable daily intake $(100-120 \mathrm{ng} / \mathrm{kg}$ bw/week) of OTA in consumed food [13-15].

Although adsorption is now recognized as a protective and efficient technique against mycotoxin contaminated diets in particular OTA in poultry feed [16-19]. Besides, some materials are selective for removal of OTA in solution includes activated charcoal, and novel carbohydrates such as $\beta$-D-glucans isolated from Saccharomyces cerevisiae and silver nanoparticles [20-23]. However, there is no available information about the efficacy of acetylated broken rice starch, dehydrated soybean hulls, and micronized wheat bran as chemically modified adsorbents against OTA in food, especially apple juice. Therefore, this work was undertaken to deal with such information.

\section{Materials and Methods}

\subsection{Materials}

Broken rice was obtained from rice variety Sakha 104 after milling and polishing of brown rice at local milling processing unit, Damietta Governorate, Egypt. Soybean hulls were obtained from Soybean Factory, Food Technology Research Institute, Agricultural Research Center, Al- Gaiza, Egypt. Wheat bran was obtained from Crops Technology Research Department, Food Technology Research Institute, Agricultural Research Center, Al-Giza, Egypt. OTA standard was purchased from Sigma, Chemical Co. (St. Louis, MO, USA). All solvents were of HPLC grade. The water was double distilled with Millipore water purification system (Bedford, M A, USA).

\subsection{Apple juice Sampling}

One hundred and fifty apple juice samples were collected randomly during the period of October to December 2016 from four commercial types of apple juices in different super markets located at Al-Giza government, Egypt. Fifty samples from each were collected monthly. These samples were stored in refrigerator at $4^{\circ} \mathrm{C}$, until further analyses.

\subsection{Methods}

\subsubsection{Isolation of Starch from Broken Rice}

Starch was isolated from broken rice according to Raina et al. [4]. Broken rice was steeped in deionized water for $18 \mathrm{hr} / 4^{\circ} \mathrm{C}$, followed by grinding in a wet grinder. The starch paste was then steeped in $0.25 \mathrm{~g} / 100 \mathrm{ml}$ alkali solution containing $0.12 \mathrm{~g} / 100 \mathrm{ml} \mathrm{Na} \mathrm{S}_{2} \mathrm{O}_{5}$ for $18 \mathrm{hr} / 4^{\circ} \mathrm{C}$, followed by decanting the supernatant. The procedure was repeated thrice. Then, the paste neutralized with $0.5 \mathrm{M} \mathrm{HCl}$ and washed thrice with distilled water to remove the salt content and filtered through a Bückner funnel under vacuum. The cake was dried at $50^{\circ} \mathrm{C}$ to about $12 \mathrm{~g} / 100 \mathrm{~g}$ moisture content. After that sample was grounded, passed through a $75-\mathrm{mm}$ sieve and stored in an airtight container at ambient temperature until further use.

\subsubsection{Acetylating of Broken Rice Starch (ARS)}

Broken rice starch was acetylated according to the method of Wolff et al. [24]. Four hundred grams of broken rice starch were dispersed in $900 \mathrm{ml}$ distilled water and stirred for 60 $\mathrm{min} / 25^{\circ} \mathrm{C}$. The obtained suspension was adjusted to $\mathrm{pH} 8.0$ using $3 \mathrm{~g} / 100 \mathrm{ml} \mathrm{NaOH}$. Acetic acid anhydride was added ( 8 and $16 \mathrm{ml} / 100 \mathrm{ml}$ respectively, on dry starch basis) to the stirred slurry, while maintaining the range within $\mathrm{pH}$ 8.0- 8.4 using $3 \mathrm{gm} / 100 \mathrm{ml} \mathrm{NaOH}$ solution. The reaction was kept for $10 \mathrm{~min}$ after acetic anhydride addition. Finally, the slurry was adjusted to $\mathrm{pH} 4.5$ using $0.5 \mathrm{M} \mathrm{HCl}$, centrifuged at $2000 \mathrm{rpm} /$ $3 \mathrm{~min}$, washed thrice with distilled water to discard any acidic residue and air-dried.

\subsubsection{Modification of Soybean HULLS (MSH)}

The soybean hulls were modified according to the method of Jia et al. [5]. Soybean hulls were sieved to obtain particle size range $0.6-1.7 \mathrm{~mm}$. About $1.0 \mathrm{~g}$ sieved sample was dissolved in $0.08 \mathrm{~mol} / \mathrm{L} \mathrm{NaOH}$ aqueous solution at $250 \mathrm{ml}$ Erlenmeyer flask. The mixture was shaken at $140 \mathrm{rpm} / 8$ $\mathrm{h} / 25^{\circ} \mathrm{C}$. Then the $\mathrm{pH}$ was neutralized with de-ionized water. Followed by, adding of $150 \mathrm{ml}$ of $0.6 \mathrm{~mol} / \mathrm{L}$ citric acid as a modified agent, and heating at $110^{\circ} \mathrm{C} / 1.5 \mathrm{~h}$. Finally, the mixture was neutralized with de-ionized water, filtered and, dried at $60^{\circ} \mathrm{C} / 24 \mathrm{~h}$.

\subsubsection{Micronized Wheat Bran (MWB)}

The wheat bran was micronized according to Özer et al. [3]. Wheat bran was sieved through 50 mesh sieve to remove any foreign materials or large solids. About $100 \mathrm{~g}$ of sieved samples were digested in $200 \mathrm{~g}$ concentrated sulfuric acid (W/W) with continuous stirring for $24 \mathrm{~h}$. Then the mixture was washed for several times with distilled water using water pump until the final $\mathrm{pH}$ was reached 3.0. At the end of the process, the dehydrated wheat bran adsorbent was screened through 50 mesh sieve and stored in a closed bottle for further use.

\subsubsection{Preparation of OTA Spiked Solution}

Stock solutions and standards of OTA were prepared and assayed according to AOAC Method 971.22 [25]. A stock solution of OTA was prepared by dissolving $1 \mathrm{mg}$ of OTA in $10 \mathrm{~mL}$ of methanol. Spiked concentration $(10 \mathrm{ng} / \mathrm{mL})$ of OTA standard were prepared by adding $10 \mu \mathrm{L}$ to $100 \mathrm{~mL}$ phosphate buffered saline (PBS).

\subsubsection{Fourier Transform Infrared Spectroscopy (FTIR)}

The characterization of functional groups on the surface of acetylated rice starch (ARS 8, ARS 16\%), modified soybean hulls (MSH), and micronized wheat bran (MWB) was performed by Fourier Transform Infrared Spectroscopy (FTIR 6100; Perkin-Elmer), and the spectra were scanned in the $400-4000 \mathrm{~cm}^{1}$ range at a resolution of $4 \mathrm{~cm}$.

\subsubsection{OTA Removal Assay with Contaminated PBS}

Chemically modified adsorbents (CMA) included $\mathrm{MSH}$, MWB, ARS $8 \%$ and ARS $16 \%$ were tested at 500 and 1000 $\mathrm{mg}$ for each $\mathrm{CMA} / 100 \mathrm{ml} \mathrm{PBS} \mathrm{W} / \mathrm{V}$ for their ability to remove OTA in contaminated PBS. CMA was added to $100 \mathrm{~mL}$ Phosphate Buffer Saline (PBS) contaminated with a 
standard working solution of OTA at $10 \mathrm{ng} / \mathrm{mL}$. Samples were shaken for $30 \mathrm{~min}$ at $25^{\circ} \mathrm{C}$. All experiments were performed in triplicate.

\subsubsection{Extraction and Determination of OTA from PBS and Apple Juice}

Apple juice samples were depurated according to Niu et al. [26] using activated $\mathrm{C}_{18}$ solid phase extraction column, Varian, Palo Alto, USA, flow rate: $1.5 \mathrm{~mL} / \mathrm{min}$, solvents: methanol/deionized water $(2: 3)$. The obtained eluents were adjusted to $2 \mathrm{~mL}$, and then stored at $-20^{\circ} \mathrm{C}$ in dark bottles prior to HPLC analysis. OTA concentrations in samples were determined by means of HPLC. The system is consisted of Waters Binary Pump Model 1525, Phenomenex $\mathrm{C}_{18}(250$ X4.6 mm, USA), solvents: acetonitrile: water: acetic acid (55:43:2), flow rate: $1.0 \mathrm{ml} / \mathrm{min}$, and the data workstation with software Breeze 2i.d. Samples were identified against standard solution of OTA in PBS using fluorescence detector operated at wavelength of $335 \mathrm{~nm}$ for excitation and $465 \mathrm{~nm}$ for emission.

\subsubsection{Efficacy of CMA for Removal of OTA from Contaminated Apple Juice Samples}

The efficacy of CMA for removal of OTA was studied in the contaminated apple juice samples with high concentration of OTA. Two concentrations of CMA (500mg and $1000 \mathrm{mg}$ ) were studied. CMA was added to the highly contaminated apple juice samples and left for $15 \mathrm{~min}$ then filtered. The percentage of reduction of OTA was calculated as $100 \%$ reduction referenced to untreated samples.

\subsubsection{Sensory Acceptability of Apple Juice Samples}

A panel of fifteen members from Food Technology Research Institute, Agricultural Research Center, Al-Giza, Egypt was used to judge the acceptability of apple juice samples after the removal of OTA using CMA followed by filtration. The panelists were asked to evaluate each sample for appearance, consistency, color, flavor and overall acceptability using a 9 point hedonic scale from 1 to 9 as follows: $1=$ extremely bad; $5=$ Satisfactory; and 9= Excellent. The order of the samples was randomized and given codes before being tested by the panelists.

\subsubsection{Statistical Analysis}

Data obtained from this study were subjected to an analysis of variance ANOVA. Duncan's multiple range test at $5 \%$ level was used to compare between means according to Steel et al. [27].

Table 1. FTIR analysis of bonds and functional groups in RS and (ARS 8 and ARS 16\%).

\begin{tabular}{|c|c|c|c|}
\hline NO. of peak & Band position $\left(\mathrm{cm}^{-1}\right)$ & bond and functional group & Type of CMA \\
\hline 1 & $3409.53-3429.78$ & O-H alcohol & All \\
\hline 2 & $2927.41-3228.25$ & $\begin{array}{l}\mathrm{C}-\mathrm{H} \text { methyl and methylene groups } \\
\mathrm{R}-\mathrm{C} \equiv \mathrm{C}-\mathrm{H} \text { Alkynes }\end{array}$ & $\begin{array}{l}\text { (RS and ARS 16\%) } \\
\text { ARS } 8 \%\end{array}$ \\
\hline 3 & $2147.35-2928.38$ & $\begin{array}{l}\mathrm{C}-\mathrm{H} \text { stretch } \\
-\mathrm{C} \equiv \mathrm{C}-\text { stretch }\end{array}$ & $\begin{array}{l}\text { (RS and ARS 8\%) } \\
\text { ARS } 16 \%\end{array}$ \\
\hline 4 & $\begin{array}{l}2852.2 \\
2049.0 \\
1729.83\end{array}$ & $\begin{array}{l}\mathrm{C}-\mathrm{H} \text { stretch } \\
\mathrm{C} \equiv \mathrm{C} \text { Alkynes } \\
\mathrm{C}=\mathrm{O} \text { Carboxylic Acid }\end{array}$ & $\begin{array}{l}\text { RS } \\
\text { ARS } 8 \% \\
\text { ARS } 16 \%\end{array}$ \\
\hline 5 & $\begin{array}{l}2057.67 \\
1723.09 \\
1647.88\end{array}$ & $\begin{array}{l}\mathrm{C} \equiv \mathrm{C} \text { Alkynes } \\
\mathrm{C}=\mathrm{O} \text { Aldehydes } \\
\mathrm{R}-\mathrm{C}(\mathrm{O})-\mathrm{NH} 2 \text { Amides }\end{array}$ & $\begin{array}{l}\text { RS } \\
\text { ARS } 8 \% \\
\text { ARS } 16 \%\end{array}$ \\
\hline
\end{tabular}

\section{Results and Discussion}

\subsection{FTIR Analysis of Chemically Modified Adsorbents (CMA)}

The FTIR analysis of bonds and functional groups in rice starch (RS), wheat bran (WB), soybean hulls (SH), and their CMA is presented in Tables $(1,2$, and 3$)$. The results in Table (1) indicated that rice starch (RS) shows the difference in C structure as well as acetylated rice starch (ARS 8 and ARS $16 \%$ ). There was strong $\mathrm{OH}$ stretching from 3300 to $4000 \mathrm{~cm}^{-}$ ${ }^{1}, \mathrm{C}-\mathrm{H}$ stretching in methyl and methylene groups from 2800 to $3000 \mathrm{~cm}^{-1}$, and a strong, broad superposition with sharp absorptions from 1000 to $1750 \mathrm{~cm}^{-1}$. The peak No. 4 showed bands positioned at $2852.2 \mathrm{~cm}^{-1}, 2049 \mathrm{~cm}^{-1}$, and $1729.83 \mathrm{~cm}^{-1}$ that may be related to methyl $\mathrm{C}-\mathrm{H}, \mathrm{C} \equiv \mathrm{C}$ alkynes, and $\mathrm{C}=\mathrm{O}$ carboxylic acid with RS, ARS 8 and ARS $16 \%$, respectively. The same with peak No. 5 which indicated that $\mathrm{C} \equiv \mathrm{C}$ alkynes, $\mathrm{C}=\mathrm{O}$ aldehydes, and $\mathrm{R}-\mathrm{C}(\mathrm{O})-\mathrm{NH}_{2}$ amides were positioned at 2057,1723 , and $1647 \mathrm{~cm}^{-1}$, respectively.

The results in Table (2) revealed that wheat bran (WB) has twenty-five bands, but the micronized wheat bran (MWB) has seventeen bands. The bands appeared at $34230.03 \mathrm{~cm}^{-1}$ correspond to the $\mathrm{O}-\mathrm{H}$ stretch, $\mathrm{H}-$ bonded alcohols, and phenols. While the band appeared at $2924.52 \mathrm{~cm}^{-1}$ corresponds to the $\mathrm{C}-\mathrm{H}$ stretch alkans, methyl and methylene groups. On the other hand, the band positioned at $1513.85 \mathrm{~cm}^{-1}$ corresponds to the $\mathrm{N}-\mathrm{O}$ asymmetric stretch Nitro compounds. The results in Table (3) indicated that soybean hulls (SH) have eighteen bands, but the modified soybean hulls (MSH) have twenty two bands. The band appeared at $3759.55 \mathrm{~cm}^{-1}$ corresponds to the $\mathrm{O}-\mathrm{H}$ stretch, $\mathrm{H}-$ bonded alcohols, and phenols. While the band appeared at $3413.39 \mathrm{~cm}^{-1}$ corresponds to the $\mathrm{N}-\mathrm{H}$ stretch amines, and amides. However, the bands positioned from 1338 to $1034 \mathrm{~cm}^{-1}$ correspond to $\mathrm{C}-\mathrm{O}$ stretch alcohols, carboxylic acids, esters, and ethers.

\subsection{The Efficacy of CMA for the Reduction of OTA}

Data presented in Figure (1) showed the percentage of OTA reduction in PBS using different CMA at $500 \mathrm{mg}$ and $1000 \mathrm{mg} / 100 \mathrm{ml}$ PBS. The results showed that the reduction of OTA was $73.2,79.5,66.5$, and $70.9 \%$ in samples treated with $500 \mathrm{mg}$ of $\mathrm{MSH}$, MWB, ARS $8 \%$ and ARS16\%, respectively. While an observed increase in the reduction of OTA using $1000 \mathrm{mg}$ of CMA was 82.7 and $84.03 \%$ after treatment with MSH and MWB, respectively. 


\begin{tabular}{llll}
\hline NO. of peak & Band position $\left(\mathbf{c m}^{-\mathbf{1}}\right)$ & bond and functional group & Type of CMA \\
\hline 6 & $1455.03-1645.95$ & C-H Alkynes & ARS $16 \%$ \\
& & R-C(O)-NH2 Amides & (RS and ARS 8\%) \\
7 & $1425.14-1422.24$ & C=C Alkanes & All \\
$8,9,10,11$ and 12 & $1373-1002$ & C-O alcohols, carboxylic acids, esters, ethers & All \\
13 & $930-932$ & O-H bend carboxylic acids & All \\
14 to 19 & $857-527$ & C-Cl stretch alkyl halides & All \\
\hline
\end{tabular}

Table 2. FTIR analysis of bonds and functional groups in $W B$ and $M W B$.

\begin{tabular}{|c|c|c|c|}
\hline NO. of peak & Band position $\left(\mathrm{cm}^{-1}\right)$ & bond and functional group & Type of CMA \\
\hline \multirow[b]{2}{*}{1} & 3902.25 & $\mathrm{C}=\mathrm{O}$ carbonyl group & WB \\
\hline & 34230.03 & $\mathrm{O}-\mathrm{H}$ stretch, $\mathrm{H}-$ bonded alcohols, phenols & MWB \\
\hline \multirow{2}{*}{2 to 3} & 3862.72 & O-H stretch, free hydroxyl alcohols, phenols & WB \\
\hline & 2924.52 & $\mathrm{C}-\mathrm{H}$ stretch alkanes methyl and methylene groups & MWB \\
\hline \multirow[b]{2}{*}{4} & 3423.03 & $\mathrm{~N}-\mathrm{H}$ stretch (amines, amides) & WB \\
\hline & 2125.14 & $\mathrm{C} \equiv \mathrm{C}$ stretch alkynes & MWB \\
\hline \multirow{2}{*}{5} & 2924.52 & $\mathrm{C}-\mathrm{H}$ stretch alkanes methyl and methylene groups & WB \\
\hline & 2049.96 & $\mathrm{C} \equiv \mathrm{C}$ stretch alkynes & MWB \\
\hline \multirow{2}{*}{6} & 2859.92 & C-H C stretch alkynes & WB \\
\hline & 1641.13 & $\mathrm{~N}-\mathrm{H}$ bend (amines) & MWB \\
\hline \multirow{2}{*}{7} & 2408.66 & O-H stretch (Carboxylic Acids) & WB \\
\hline & 1513.85 & $\mathrm{~N}-\mathrm{O}$ asymmetric stretch nitro compounds & MWB \\
\hline \multirow{2}{*}{8} & 2137.71 & $\mathrm{C} \equiv \mathrm{C}$ stretch alkynes & WB \\
\hline & 1428.03 & $\mathrm{C}-\mathrm{C}$ stretch (in-ring) aromatics & MWB \\
\hline \multirow{2}{*}{9} & 1992.11 & $\mathrm{C} \equiv \mathrm{C}$ stretch alkynes & WB \\
\hline & 1382.71 & C-H alkanes & MWB \\
\hline \multirow{2}{*}{10} & 1916.9 & $\mathrm{C} \equiv \mathrm{C}$ stretch alkynes & WB \\
\hline & $1328 . .71$ & C-O stretch alcohols, carboxylic acids, esters, & MWB \\
\hline \multirow{2}{*}{11} & 1645.95 & $\mathrm{~N}-\mathrm{H}$ bend $1^{\circ}$ amines & WB \\
\hline & 125254 & $\mathrm{C}-\mathrm{N}$ stretch aromatic amines & MWB \\
\hline \multirow{2}{*}{12} & 1549.52 & $\mathrm{~N}-\mathrm{O}$ asymmetric stretch nitro compounds & WB \\
\hline & 1157.08 & $\mathrm{C}-\mathrm{H}$ wag $(-\mathrm{CHX})$ alkyl halides & MWB \\
\hline \multirow{2}{*}{13} & 1515.78 & C-C stretch & WB \\
\hline & 1106.94 & $\mathrm{C}-\mathrm{N}$ stretch aliphatic amines & MWB \\
\hline \multirow{2}{*}{14} & 1426.1 & $\mathrm{C}-\mathrm{C}$ (aromatics) & WB \\
\hline & 1042.34 & $\mathrm{C}-\mathrm{N}$ stretch aliphatic amines & MWB \\
\hline \multirow{2}{*}{15} & 1380.78 & $\mathrm{C}-\mathrm{H}$ alkanes & WB \\
\hline & 899.63 & $\mathrm{C}-\mathrm{H}$ aromatics & MWB \\
\hline \multirow{2}{*}{16} & 1250.61 & $\mathrm{C}-\mathrm{N}$ stretch aromatic amines & WB \\
\hline & 662.428 & $=\mathrm{C}-\mathrm{H}$ alkynes & MWB \\
\hline \multirow{2}{*}{17} & 1157.08 & $\mathrm{C}-\mathrm{H}$ wag $(-\mathrm{CHX})$ alkyl halides & WB \\
\hline & 606.503 (end) & $\mathrm{C}-\mathrm{Br}$ stretch alkyl halides & MWB \\
\hline
\end{tabular}

Table 3. FTIR analysis of bonds and functional groups in SH and MSH.

\begin{tabular}{|c|c|c|c|}
\hline NO. of peak & Band position $\left(\mathrm{cm}^{-1}\right)$ & bond and functional group & Type of CMA \\
\hline 1 & $\begin{array}{l}3746.05 \\
3759.55\end{array}$ & $\begin{array}{l}\text { O-H stretch, free hydroxyl } \\
\text { ( alcohols, phenols) }\end{array}$ & SH and MSH \\
\hline 2 & $\begin{array}{l}3419.17 \\
3413.39\end{array}$ & $\mathrm{~N}-\mathrm{H}$ stretch (amines, amides) & SH and MSH \\
\hline 3 & $\begin{array}{l}3011.3 \\
3009.37\end{array}$ & $\mathrm{C}-\mathrm{H}$ stretch aromatics & SH and MSH \\
\hline 4 & $\begin{array}{l}2926.45 \\
2025.48\end{array}$ & $\mathrm{C}-\mathrm{H}$ stretch alkanes methyl and methylene groups & SH and MSH \\
\hline 5 & 2857.99 & C-H C stretch alkynes & SH and MSH \\
\hline 6 & $\begin{array}{l}2109.74 \\
1742.37\end{array}$ & $\begin{array}{l}\mathrm{C} \equiv \mathrm{C} \text { stretch alkynes } \\
\mathrm{C}=\mathrm{O} \text { stretch esters, saturated aliphatic }\end{array}$ & $\begin{array}{l}\mathrm{SH} \\
\mathrm{MSH}\end{array}$ \\
\hline 7 & $\begin{array}{l}1649.8 \\
1640.16\end{array}$ & $-\mathrm{C}=\mathrm{C}-$ stretch alkenes & SH and MSH \\
\hline 8 & $\begin{array}{l}1546.63 \\
1543.74\end{array}$ & $\mathrm{~N}-\mathrm{O}$ asymmetric stretch nitro compounds & SH and MSH \\
\hline 9 & $\begin{array}{l}1451.17 \\
1430.92\end{array}$ & $\mathrm{C}-\mathrm{H}$ bend alkanes & SH and MSH \\
\hline 10 & $\begin{array}{l}1411.64 \\
1381 . .75\end{array}$ & $\begin{array}{l}\text { C-C (aromatics) } \\
\text { C-H alkanes }\end{array}$ & $\begin{array}{l}\text { SH } \\
\text { MSH }\end{array}$ \\
\hline
\end{tabular}




\begin{tabular}{llll}
\hline NO. of peak & Band position $\left(\mathbf{c m}^{-\mathbf{1}}\right)$ & bond and functional group & Type of CMA \\
\hline 11 to 15 & 1338 to1034 & C-O stretch alcohols, carboxylic acids, esters, ethers & SH and MSH \\
16 and 17 & 897 to 612 & C-H “oop" aromatics & SH and MSH \\
18 & 431 & C-Br stretch alkyl halides & SH and MSH \\
19 to 22 & 608 & C-Cl stretch alkyl halides & MSH \\
\hline
\end{tabular}

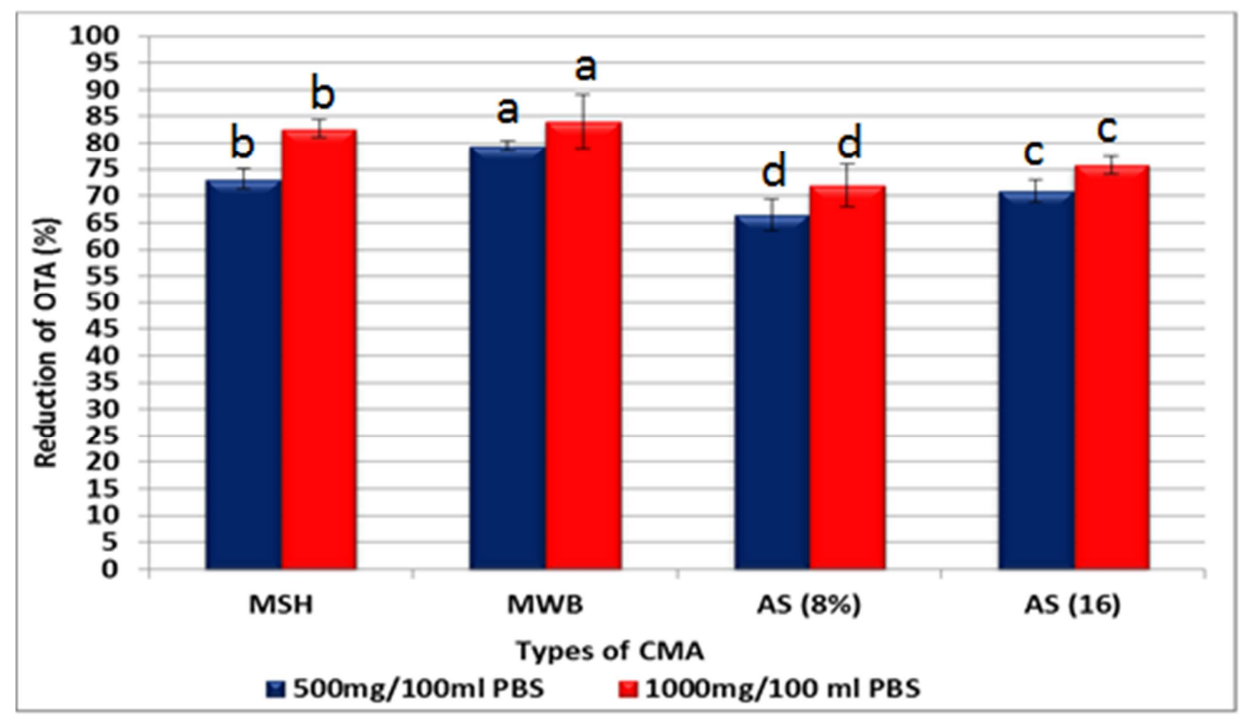

Figure 1. The percentages of reduction of OTA in PBS treated with 500mg and 100mg of CMA.

While an observed increase in the reduction of OTA using $1000 \mathrm{mg}$ of CMA was 82.7 and $84.03 \%$ after treatment with MSH and MWB, respectively. In case of ARS $8 \%$ and ARS $16 \%$ the OTA reduction was 72.0 , and $75.8 \%$, respectively. The analysis of variance showed significant differences between the type and concentration of CMA, where MWB> MSH $>$ ARS16>ARS $8 \%$. The reduction of OTA may be due to many of the functional groups (carboxyl, polysaccharides, hydroxyl, lipids, and amino) that react with or adsorb OTA. Many studies used many materials as adsorbents for removal or reduction of OTA, including bentonite, cellulose acetate esters, polyvinylpyrrolidone, cholestyramine, and polygel [28-30].

\subsection{Incidence of OTA in Apple Juice Samples}

Table (4) represents the incidence and concentration of

OTA in apple juice samples obtained during October till December 2016. Also, Figure (2) depicts the OTA HPLC chromatogram of the standard and the positive contaminated apple juice samples. OTA was detected in October in 7 positive samples (14\%) out of 50 samples. The concentration of contamination in these samples ranged from 1.52 to 4.27 ppb. The highest incidence was observed in November with
17 positive samples in a total of 50 samples $(34.0 \%)$. The concentrations of contamination in these samples ranged from 0.85- $3.26 \mathrm{ppb}$. On the other hand, during December eighteen percent $(18 \%)$ of samples were contaminated with OTA and ranged from 1.16 to $5.23 \mathrm{ppb}$. The results indicated that thirteen samples under the study exceeded the permissible limits (2 ppb) as recommended by the EU $1881 / 2006$ [31]. OTA is a frequent contaminant of fruit beverages and juices, caused mainly by black Aspergilli, especially $A$. carbonarius, as results from poor agricultural and harvesting practices, especially in the case of physical and physiological damage [32-33]. In addition to the OTA is comparatively heat resistant within the range of applied thermal processing conditions with juices. However, OTA is partially destroyed during fermentation procedures, so it can also be found in various industrial food products [11]. In Saudi Arabia, Al-Hazmi [34] reported that OTA was discovered in apple juice samples in 5 types out of 17 types $(29.41 \%)$. Besides, the concentration of OTA in positive samples ranged from 100 to $200 \mathrm{ppb}$. In Brazil, Rosa et al. [35] found that $25 \%$ out of 64 samples of grape juices and frozen pulps were positive for OTA with mean and maximum concentration of $37 \mathrm{ppb}$ and $100 \mathrm{ppb}$, respectively.

Table 4. Incidence of OTA in four commercial types of apple juices in Egypt market.

\begin{tabular}{lllll}
\hline Months & No. of samples & No. of positive samples & Minimum- Maximum (ppb)* & No. of samples exceeded permissible limits* \\
\hline October & & $7(14 \%)$ & $1.52-4.27$ & 4 \\
November & 50 & $17(34 \%)$ & $0.85-3.26$ & 6 \\
December & & $9(18 \%)$ & $1.16-5.23$ & 3 \\
\hline
\end{tabular}




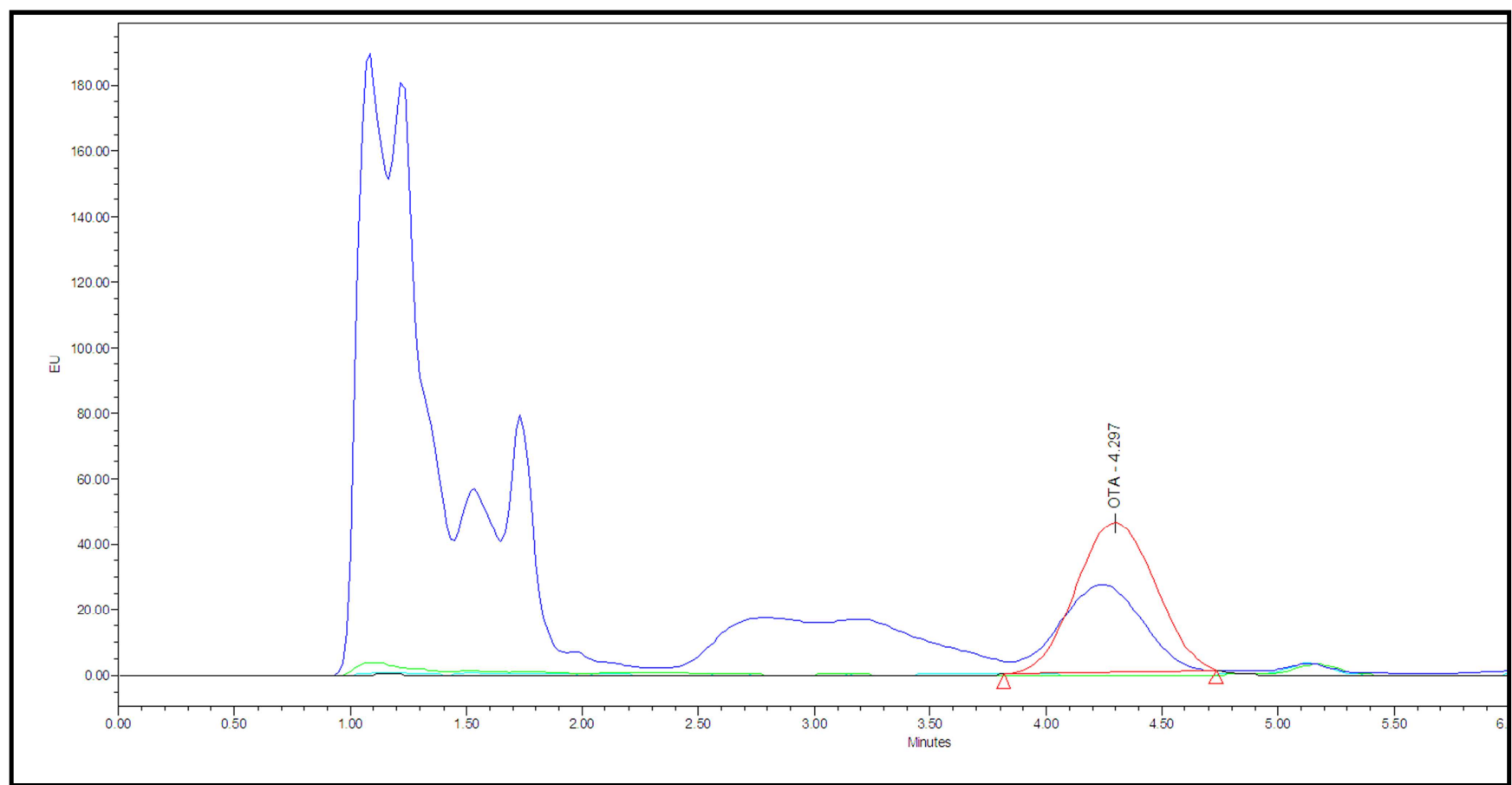

OTA: Ochratoxin A*(ppb): part per billion, the permissible limits (2ppb)

Figure 2. HPLC chromatogram of stander OTA and positive sample of apple juice.

\subsection{Efficacy of CMA for Removal of OTA from Contaminated Apple Juice Samples}

The results of the efficacy of CMA for removal of OTA from contaminated apple juice samples are presented in Figure (3). Data showed that the removal of OTA from all contaminated apple juice samples was $100 \%$. Accordingly, it could be recommended that processors can reduce the level of OTA in apple juice by adding these CMA in the final stream of the production process, after complete homogenization, followed by filtration.

\subsection{Sensory Acceptability of the Treated Apple Juice Samples}

Sensory evaluation of control and treated apple juice samples with different CMA after removal of OTA, followed by filtration are presented in Table (5). The results indicated that the treated apple juice samples were accepted by the panelists and there were no significant differences as regard to appearance, color, flavor, and overall acceptability.
However, there was a partial significant difference as regard to consistency. Although future studies were required for studying the effect of these substances on the potential nutrients excited in the apple juice.

\section{Conclusions}

Acetylating, microniztion, and dehydration with acids, as chemical modification methods could be used to add stretching bonds and new functional groups at different band positions on broken rice starch, soybean hulls, and wheat bran. That is to improve the adsorption capacity of these field crops by- products against OTA in spiked solution and at contaminated apple juice. It could be recommended that processors can reduce the level of OTA in contaminated apple juice by adding these CMA in the final stream of the production process, after complete homogenization, followed by filtration, with no significant changes in its sensory characteristics.

Table 5. Sensory acceptability of the treated apple juice samples.

\begin{tabular}{lllll}
\hline Juice samples & Appearance & consistency & color & flavor \\
\hline Untreated & $8.7 \pm 0.7^{\mathrm{a}}$ & $8.8 \pm 0.8^{\mathrm{a}}$ & $8.6 \pm 0.6^{\mathrm{a}}$ & $8.9 \pm 0.6^{\mathrm{a}}$ \\
ARS 8\% & $8.1 \pm 1.7^{\mathrm{ab}}$ & $7.4 \pm 1.4^{\mathrm{c}}$ & $8.0 \pm 1.3^{\mathrm{ab}}$ & $8.5 \pm 2.1^{\mathrm{ab}}$ \\
ARS 16\% & $8.1 \pm 1^{\mathrm{ab}}$ & $7.5 \pm 0.9^{\mathrm{c}}$ & $8.1 \pm 1.3^{\mathrm{ab}}$ & $8.9 \pm 0.75^{\mathrm{a}}$ \\
MWB & $8.3 \pm 1.2^{\mathrm{ab}}$ & $7.8 \pm 0.7^{\mathrm{b}}$ & $8.4 \pm 1.2^{\mathrm{a}}$ & $8.2 \pm 0.6^{\mathrm{ab}}$ \\
MSH & $8.7 \pm 0.8^{\mathrm{a}}$ & $7.8 \pm 1.2^{\mathrm{b}}$ & $8.7 \pm 0.7^{\mathrm{a}}$ & $8.7 \pm 0.7^{\mathrm{a}}$ \\
\hline
\end{tabular}

*OAA-overall acceptability.

ARS- acetylated rice starch, MWB- micronized wheat bran, MSH- modified soybean.

Data are presented as means \pm SDM $(n=15$, a 9-point hedonic scale) \& Means within a column with different letters are significantly different at $\mathrm{P} \geq 0.05$. 


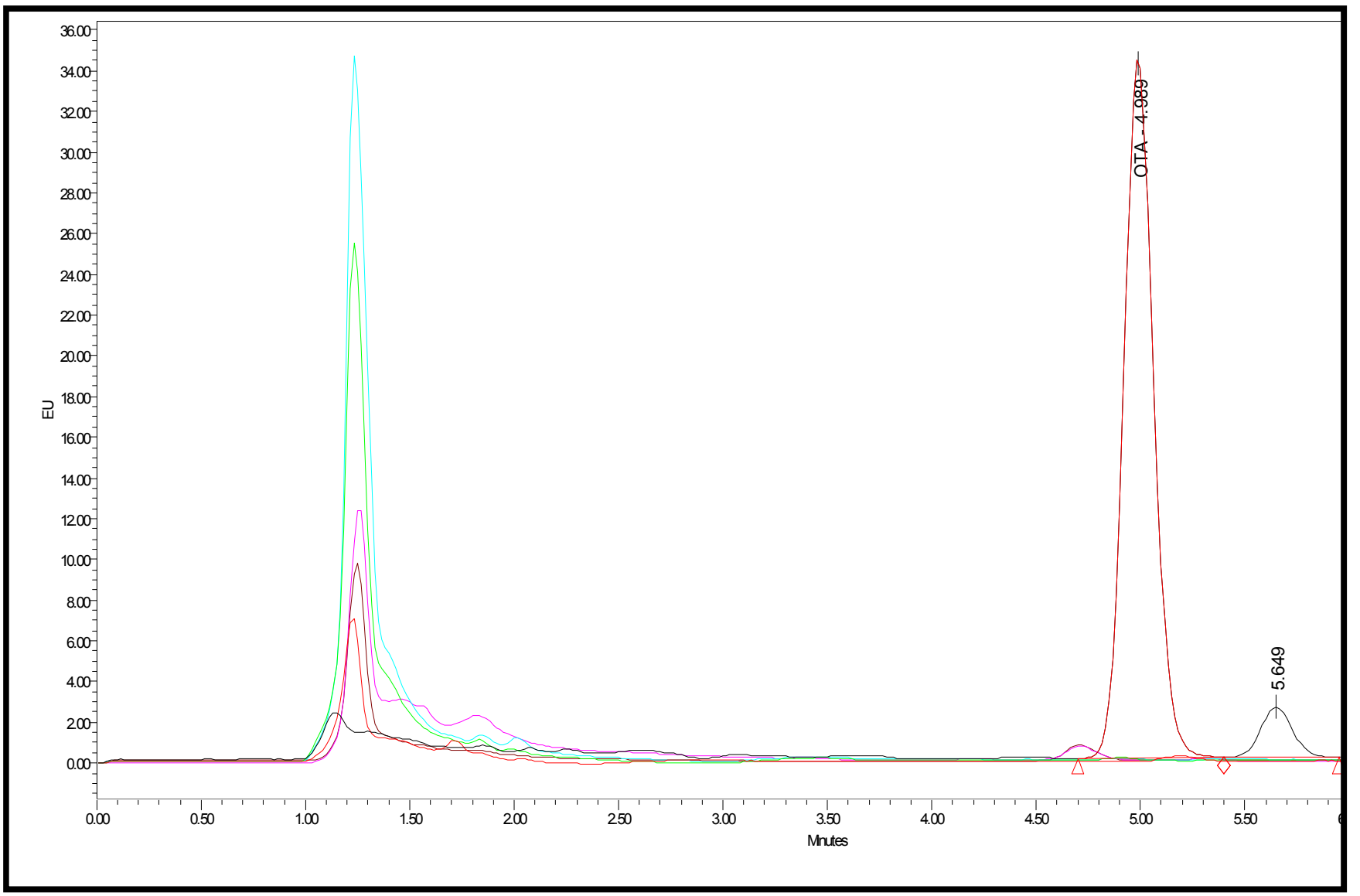

Figure 3. HPLC chromatogram of OTA in apple Juice treated by different CMA

\section{Acknowledgements}

The authors would like to thank the Food Technology Research Institute, the National Research Centre, and Prof. Dr. Khayria Naguib for supported the completion of this study.

\section{References}

[1] Chandiposha M, Ignatius C and Veronica M (2013). a review: Utilization of common grain crops in Zimbabwe. African Journal of Food Science, 7: 253-257.

[2] Ahmed, K., Nizami, S., \& Riza, Z. (2014). Reinforcement of natural rubber hybrid composites based on marble sludge/Silica and marble sludge/rice husk derived silica. Journal of Advanced Research, 5: 165-173.

[3] Özer, A., Özer, D., and Özer, A. (2004). The adsorption of copper (II) ions on to dehydrated wheat bran (DWB): determination of the equilibrium and thermodynamic parameters. Process Biochemistry, 39: 2183-2191.

[4] Raina, C. S., Singh, S., Awa, A. S. B, \& Saxena, D.C. (2006). Rheological properties of chemically modified rice starch model solutions. Journal of Food Process Engineering, 29: 134-148.

[5] Jia, L., Enzan, C., Haijia, S. and Tianwei,, T. (2011). Biosorption of $\mathrm{Pb}^{2+}$ with modified soybean hulls as absorbent. Chinese Journal of Chemical Engineering, 19 (2): 334-339.
[6] Alves, C. C. O., Franca, A. S., and Oliveira, L. S. (2013) Removal of phenylalanine from aqueous solutions with thermo-chemically modified corn cobs as adsorbents. $L W T$ Food Science and Technology, 5.

[7] Singha, AS., and Guleria, A. (2015). Utility of chemically modified agricultural waste okra biomass for removal of toxic heavy metal ions from aqueous solution. Engineering in Agriculture, Environment and Food, 8: 52-60. 1: 1-8.

[8] Kamel, S., Abou-Yousef, H., Yousef, M. and El-Sakhawy, M. (2012). Potential use of bagasse and modified bagasse for removing of iron and phenol from water. Carbohydrate Polymer; 88:250-256.

[9] Casal, S., Vieira, T., Cruz, R. and Cunha, S. C. (2014). Ochratoxin A in commercial soluble coffee and coffee substitutes. Food research international, 61: 56- 60.

[10] IARC: International Agency for Research on Cancer (1993). Summaries \& Evaluations ochratoxin A (Group 2B) For definition of Groups,: 56: 489 (CAS No.: 303-47-9.

[11] Bosco, F. and Mollea, C. (2012). Mycotoxins in Food, In: Food Industrial Processes-Methods and Equipment, Edited by Benjamin Valdez, Published by InTech Lai, X., Ruan, C. Liu, R.\& Liu, C. (2014). Application of ionic liquid- based dispersive liquid-liquid microextraction for the analysis of ochratoxin A in rice wines. Food Chemistry, 161:317-322.

[12] Lai, X., Ruan, C. Liu, R. and Liu, C. (2014). Application of ionic liquid- based dispersive liquid-liquid microextraction for the analysis of ochratoxin A in rice wines. Food Chemistry, 161: $317-322$ 
[13] EFSA (2006). Opinion of the Scientific Panel on Contaminants in the Food Chain on a request from the Commission related to ochratoxin $\mathrm{A}$ in food, question $\mathrm{N}$ EFSA-Q- 2005-154, adopted on 4 April 2006. The EFSA Journal, 365(1-56).

[14] EU, European Commission (2010). Commission Regulation (EC) No 105/2010 of 5 February. Amending Regulation (EC) n 105/2010 as regards ochratoxin A toxins. Official Journal of the European Union, L 35, 7-8.

[15] Gil-Serna, J., Vázquez, C., Sandino, F., Valle, A., GonzálezJaén, M. and Patiño, B. (2014). Evaluation of growth and ochratoxin A production by Aspergillus steynii and Aspergillus westerdijkiae in green- coffee based medium under different environmental conditions. Food research international, 61: 127-131

[16] Campagnollo FB, Franco LTand Rottinghaus GE. (2015). In vitro evaluation of the ability of beer fermentation residue containing Saccharomyces cerevisiae to bind mycotoxins. Food research international, 77: 643-648.

[17] Alcano, M. J., Jahn, R. C., Scherer, C. D. Wigmann, É. F., Moraes, V. M., Garcia, M. V., Mallmann, C. A., and Copetti, M. V. (2016). Susceptibility of Aspergillus spp. to acetic and sorbic acids based on $\mathrm{pH}$ and effect of sub-inhibitory doses of sorbic acid on ochratoxin A production. Food Research International, 81: 25-30.

[18] Bhatti SA, Khan MZ, and Saleemi MK. (2016). Aflatoxicosis and ochratoxicosis in broiler chicks and their amelioration with locally available bentonite clay. Pakistan Veterinary Journal, 36:68-72.

[19] Qu, D. Huang, X. Han, J. and Man, N. (2017). Efficacy of mixed adsorbent in ameliorating ochratoxicosis in broilers fed ochratoxin A contaminated diets. Italian Journal of Animal Science, pp. 7.

[20] Yiannikouris, A.; André, G.; Poughon, L.; François, J.; Dussap, C.-G.; Jeminet, G.; Bertin, G. and Jouany, J. P.(2006) Chemical and conformational study of the interactions involved in mycotoxin complexation with $\beta$-D-glucans. Biomacromolecules 7, 1147-1155.

[21] Espejo, F and Armada, S. (2009). Effect of activated carbon on ochratoxin A reduction in "Pedro Ximenez"sweet wine made from off-vine dried grapes. Eur. Food Res. Technol. 229, 255-262.

[22] Solfrizzo, M.; Avantaggiato, G.; Panzarini, G and Visconti, A. (2009). Removal of ochratoxin A from contaminated red wines by repassage over grape pomaces. J. Agric. Food Chem. 58, 317-323.
[23] El-Desouky T. A and Ammar HAM (2016). Honey mediated silver nanoparticles and their inhibitory effect on aflatoxins and ochratoxin A. J App Pharm Sci, 6 (06): 083-090.

[24] Wolff, I. A., Olds, D. W., and Hilbert, G. E. (1951). Acetylation of starch, amylose, and amylopectin. Journal of the American Chemical Society, 73: 346- 349.

[25] AOAC (2005). Association of Official Analytical Chemists. Official methods of analysis $18^{\text {th }}$. Washington D.C., USA.

[26] Niu, Y., Wang, X., Yu, J., Ma, L., and Zhan, J. (2009). Optimization of solid-phase extraction for the detection of ochratoxin A in grape wine. Liquor-Making Science\&Technology, 6, 24-27.

[27] Steel RGD, Torrie, JH and Dickey DA. (1997). Principles and Procedures of Statistics. A Biometrical approach. McGraw Hill Book Co., New York, USA.

[28] Gambuti, A.; Strollo, D.; Genovese, A.; Ugliano, M.; Ritieni, A.; Moio, L. (2005). Influence of enological practices on ochratoxin A concentration in wine. Am. J. Enol. Viticult. 56, 155-162.

[29] Visconti, A.; Perrone, G.; Cozzi, G.; Solfrizzo, M.(2008). Managing ochratoxin A risk in the grape-wine food chain. Food Addit. Contam. 25, 193-202.

[30] Var, I.; Kabak, B.; Erginkaya, Z. (2008). Reduction in ochratoxin A levels in white wine, following treatment with activated carbon and sodium bentonite. Food Control, 19, 592-598.

[31] European Commission. (2006). Commission regulation (EC) No 1881/2006 of 19 December 2006 setting maximum levels for certain contaminants in foodstuffs. Official Journal of the European Union, L364, 5-24

[32] Delage, N., d'Harlingue, A., Colonna Ceccaldi, B., and Bompeix, G. (2003). Occurrence of mycotoxins in fruit juices and wine. Food Control, 14(4), 225-227.

[33] Soufleros, E. H., Tricard, C., and Bouloumpasi, E. C. (2003). Occurrence of ochratoxin A in Greek wines. Journal of the Science of Food and Agriculture, 83(3), 173-179.

[34] Al-Hazmi, N. A. (2010). Determination of Patulin and Ochratoxin A using HPLC in apple juice samples in Saudi Arabia. Saudi Journal of Biological Sciences, 17: 353- 359.

[35] Rosa, C. A. R., Magnoli, C. E., Fraga, M. E., Dalcero, A. M., \& Santana, D. M. N. (2004). Occurrence of ochratoxin A in wine and grape juice marketed in Rio de Janeiro, Brazil. Food Additives and Contaminants, 21: 358-364. 